\title{
Removal Action Work Plan for the CPP-603A Basin Facility
}

\author{
June 2006
}


ICP/EXT-05- DOE/NE-ID-11214

Project No. 23943

\section{Removal Action Work Plan for the CPP-603A Basin Facility}

June 2006

Idaho Cleanup Project

Idaho Falls, Idaho 83415

Prepared for the

U.S. Department of Energy

Assistant Secretary for Environmental Management Under DOE Idaho Operations Office

Contract DE-AC07-05ID14516 



\begin{abstract}
This revised Removal Action Work Plan describes the actions to be taken under the non-time-critical removal action recommended in the Action Memorandum for the Non-Time Critical Removal Action at the CPP-603A Basins, Idaho Nuclear Technology and Engineering Center, as evaluated in the Engineering Evaluation/Cost Analysis for the CPP-603A Basin Non-Time Critical Removal Action, Idaho Nuclear Technology and Engineering Center. The regulatory framework outlined in this Removal Action Work Plan has been modified from the description provided in the Engineering Evaluation/Cost Analysis (DOE/NE-ID-11140, Rev. 1, August 2004). The modification affects regulation of sludge removal, treatment, and disposal, but the end state and technical approaches have not changed. Revision of this document had been delayed until the basin sludge was successfully managed. This revision (Rev 1) has been prepared to provide information that was not previously identified in Rev 0 to describe the removal, treatment, and disposal of the basin water at the Idaho National Laboratory (INL) CERCLA Disposal Facility evaporation ponds and fill the basins with grout/controlled low strength material (CLSM) was developed. The Engineering Evaluation/Cost Analysis for the CPP-603A Basin Non-Time Critical Removal Action, Idaho Nuclear Technology and Engineering Center - conducted pursuant to the Comprehensive Environmental Response, Compensation, and Liability Act - evaluated risks associated with deactivation of the basins and alternatives for addressing those risks. The decision to remove and dispose of the basin water debris not containing uranium grouted in place after the sludge has been removed and managed under the Hazardous Waste Management Act/Resource Conservation and Recovery Act has been documented in the Action Memorandum for the Non-Time Critical Removal Action at the CPP-603A Basins, Idaho Nuclear Technology and Engineering Center.
\end{abstract}




\section{CONTENTS}

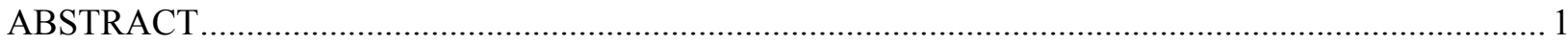

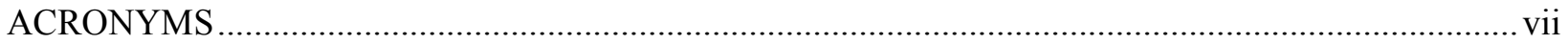

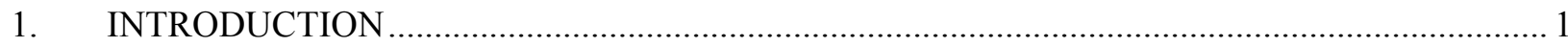

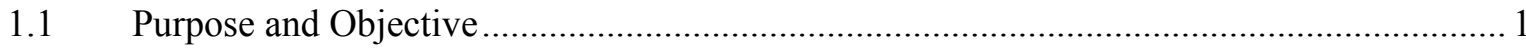

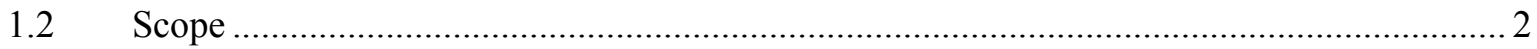

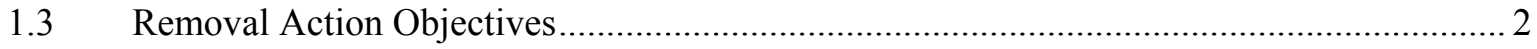

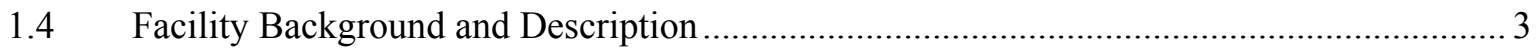

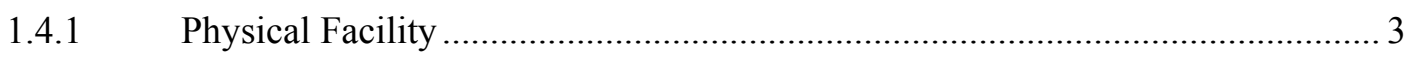

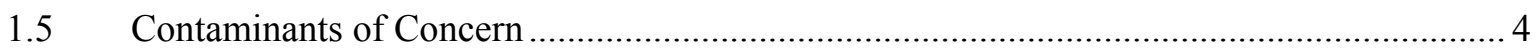

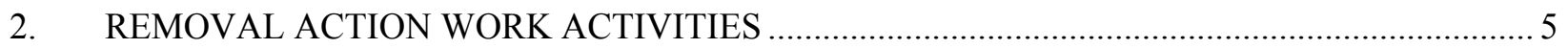

2.1 Sludge Removal, Treatment, and Disposal ........................................................... 6

2.2 Removal of the Small High-Activity Debris Object (SHADO 1) ................................... 7

2.3 Consolidation and Location of Cobalt-60 Containing Debris ........................................... 8

2.4 Basin Water Removal, Treatment, and Disposal and Filling the Basins with Grout/CLSM 8

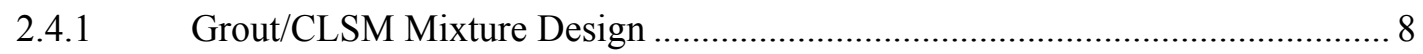

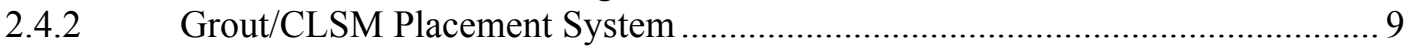

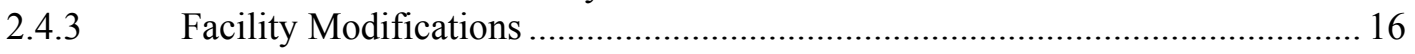

2.4.4 Water Removal System Design.............................................................. 16

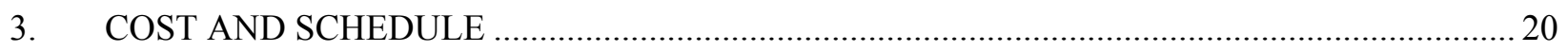

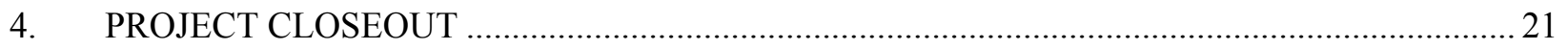

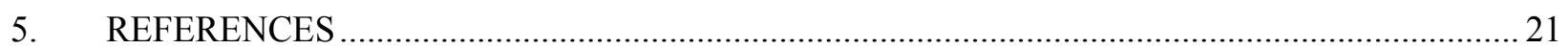




\section{FIGURES}

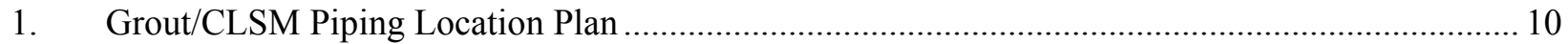

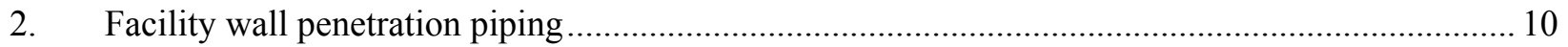

3. North and Middle Basins Grout/CLSM Placement Plan ............................................................ 12

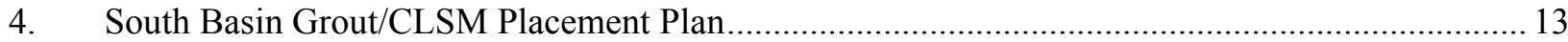

5. North and Middle Basins Grout/CLSM Placement .............................................................. 14

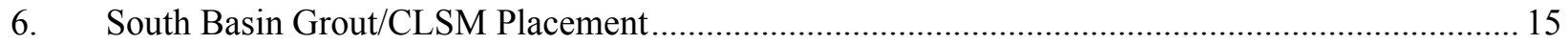

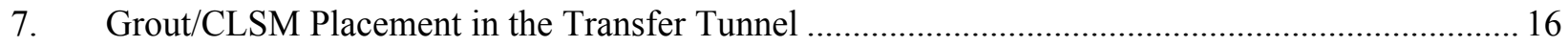

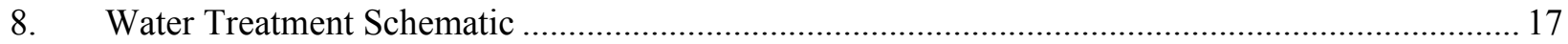

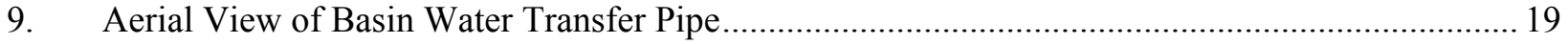

TABLES

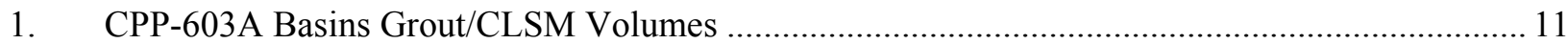

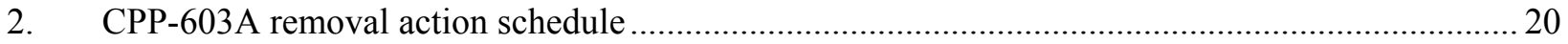




\section{ACRONYMS}

ALARA as low as reasonably achievable

CERCLA Comprehensive Environmental Response, Compensation, and Liability Act

CFR Code of Federal Regulations

CLSM controlled low strength material

CPP Chemical Processing Plant

DOE U.S. Department of Energy

DOE-ID U.S. Department of Energy Idaho Operations Office

EPA U.S. Environmental Protection Agency

FECF Fuel Element Cutting Facility

HDPE High Density Polyethylene

HICs High-Integrity Containers

HWMA Hazardous Waste Management Act

ICDF INL CERCLA Disposal Facility

IFSF Irradiated Fuel Storage Facility

INEEL Idaho National Engineering and Environmental Laboratory

INL Idaho National Laboratory

INTEC Idaho Nuclear Technology and Engineering Center

RCRA Resource Conservation and Recovery Act

RWMC Radioactive Waste Management Complex

SHADO small high-activity debris object

TSS Total Suspended Solids

USC United States Code

WAC Waste Acceptance Criteria

WAG Waste Area Group 


\section{Removal Action Work Plan for the CPP-603A Basin Facility}

\section{INTRODUCTION}

\subsection{Purpose and Objective}

This Removal Action Work Plan has been revised to describe in detail the actions to be taken under the non-time-critical removal action recommended in the Action Memorandum for the Non-Time Critical Removal Action at the CPP-603A Basins, Idaho Nuclear Technology and Engineering Center (DOE-ID 2005), as evaluated in the Engineering Evaluation/Cost Analysis for the CPP-603A Basin Non-Time Critical Removal Action, Idaho Nuclear Technology and Engineering Center (DOE-ID 2004). The regulatory framework outlined in this Removal Action Work Plan has been modified from the description provided in the Engineering Evaluation/Cost Analysis (DOE-ID 2004). The modification affects regulation of sludge removal, treatment, and disposal, but the end state and technical approaches have not changed. Removal, treatment, and disposal of the basin water and placement of grout/controlled low strength material (CLSM) in the basins will be initiated after successful removal, treatment, and disposal of the basin sludge. Revision of this document has been delayed until the basin sludge was successfully managed. This revision (Rev 1 ) has been prepared to provide information that was not previously identified in Rev 0 to describe the removal, treatment, and disposal of the basin water at the Idaho National Laboratory (INL) CERCLA Disposal Facility evaporation ponds and fill the basins with grout/CLSM was developed. The Engineering Evaluation/Cost Analysis - conducted pursuant to the Comprehensive Environmental Response, Compensation, and Liability Act (CERCLA) (42 United States Codes [USC] $\S 9601$ et seq.) — evaluated the risks associated with the sludge and the alternatives for addressing those risks. A decision was made to address the sludge under the Hazardous Waste Management Act/Resource Conservation and Recovery Act (HWMA/RCRA) (Idaho Code $\S 39-4401$ et seq.; 42 USC $\S 6901$ et seq.).

The Chemical Processing Plant (CPP) -603A basin facility is located at the Idaho Nuclear Technology and Engineering Center (INTEC) at the U.S. Department of Energy's (DOE's) INL (formally the Idaho National Engineering and Environmental Laboratory [INEEL]) in Butte County, Idaho. The Final Record of Decision Idaho Nuclear Technology and Engineering Center, Operable Unit 3-13 (DOE-ID 1999) governs CERCLA sites within the INTEC facility designated as Waste Area Group (WAG) 3. Therefore, this CERCLA removal action will be consistent with the remedial action objectives established in the Final Record of Decision (DOE-ID 1999).

The recommended action identified in the Action Memorandum (DOE-ID 2005) is to perform interim stabilization of the basins. The sludge in the basins will be removed and treated in accordance with the HWMA/RCRA (Idaho Code $\S 39-4401$ et seq.; 42 USC $\S 6901$ et seq.). The scope of this nontime-critical removal action includes removing a small high-activity debris object (SHADO 1); removing, treating, and disposing of the basin water; and filling the basins with grout/CLSM. The basin water will be removed while the basins are being filled with grout/CLSM to minimize exposure of the contaminated scum line. Debris objects containing radioactive cobalt (cobalt-60) have been consolidated into three carbon steel boxes located in the South Basin and will be encapsulated in the grout/CLSM. The position of these debris objects has been recorded to facilitate future location and removal, if necessary. The grout/CLSM will also provide shielding for the radioactive contamination embedded in the basin walls, thereby minimizing possible migration and airborne contamination. This Removal Action Work Plan uses the term "debris" to refer to both radioactive and nonradioactive materials in the basins. The terms "debris" and "debris objects" are used in the document to refer to 14 discrete, highly radioactive objects 
that were sitting on the basin floor as well as a variety of nonradioactive hand tools and general rubbish inadvertently dropped in the basins over the years. The water will be pumped to the INL CERCLA Disposal Facility (ICDF) evaporation ponds and evaporated. The final decontamination and disposition of the basin structure will be evaluated when the entire CPP-603 Complex is taken out of service. This non-time-critical removal action is an interim action that will reduce the risks to human health, the environment, and site workers by minimizing the potential for release of hazardous substances. This interim action does not prejudice the final end-state alternative.

This removal action is consistent with the Final Record of Decision (DOE-ID 1999), thus supporting the overall remediation goals at WAG 3. The Final Record of Decision requires that, if contaminated soil exists beneath a building, the building must be maintained to prevent moisture infiltration and to prevent exposure to current industrial workers. Once decontamination and decommissioning of the building have been completed, and if contaminated soil exists under the footprint of the former building, the soil that exceeds the WAG 3 soil remediation goals must be either excavated or capped with an engineered barrier.

\subsection{Scope}

The scope of the activities addressed by this Removal Action Work Plan include consolidation and recording the location of the previously identified debris objects containing radioactive cobalt (cobalt-60) (completed in January 2005) and removal and relocation of the SHADO 1 (completed in March 2005). Additional highly radioactive activated metal has been located during sludge removal activities. The newly identified material has been isolated and will be consolidated with the previously identified cobalt60 contaminated material before basin water removal and basin filling is initiated. Scope yet to be completed includes removing and pumping the basin water to the ICDF evaporation ponds and placing grout/CLSM in the basins. Grout/CLSM will be placed in the basins as water is pumped to maintain a relatively constant water level to shield the radioactive contamination near the top of the basin walls.

Other activities have occurred in conjunction with the activities described in this Removal Action Work Plan. The removal, treatment, and disposal of the basin sludge took place in conjunction with this removal action but was conducted in accordance with the HWMA/RCRA (Idaho Code § 39-4401 et seq.; 42 USC $\S 6901$ et seq.). In addition, further characterization activities may be ongoing during the removal action at the CPP-603A basin facility. Additional hazardous materials and radionuclide contamination may be located or detected, thereby triggering the need for additional characterization.

\subsection{Removal Action Objectives}

This action is consistent with the remedial action objectives established in the Final Record of Decision (DOE-ID 1999). As such, the removal action will be consistent with and will contribute to the overall remediation of INTEC under CERCLA (42 USC $\S 9601$ et seq.).

The removal action objectives for this non-time-critical removal action are as follows:

- Reduce the risk to the Snake River Plain Aquifer by removing the basin water. This water, if released, could serve as a driving force to move existing vadose zone contaminants to the aquifer.

- $\quad$ Provide a mechanism for the permanent, safe disposition of radioactive water currently in the CPP-603A basins while safely stabilizing the cobalt- 60 contaminated objects as well as the non-uranium containing debris and rubbish until an end state for the CPP-603 Complex is identified. 
- $\quad$ Minimize the risk posed by contaminants remaining at the CPP-603A basins after the removal action so it does not exceed a cumulative carcinogenic risk level of $1 \times 10^{-4}$ and a total hazard index of one for future residents in 2095 and for current workers.

- $\quad$ Prevent migration of contaminants and minimize the risk posed by contaminants remaining at the CPP-603A basins after the removal action so it does not exceed a cumulative carcinogenic risk level of $1 \times 10^{-4}$ and a total hazard index of one for future residents in 2095 and for current workers.

The removal action goals are predicated on the current and future land uses established for INTEC in the Final Record of Decision (DOE-ID 1999), which includes industrial land use until at least 2095. The groundwater-ingestion exposure pathway is assumed to be the only viable exposure pathway. A surface exposure pathway does not exist from CPP-603A, since the non-uranium containing debris is present $20 \mathrm{ft}$ below ground surface, the water will be removed, and the basins will be filled with an inert material. This is consistent with the Final Record of Decision (DOE-ID 1999), where surface pathway risks are assumed to occur for contamination from ground surface to $10 \mathrm{ft}$ below ground surface.

\subsection{Facility Background and Description}

The INTEC, located in the south-central area of the INL, began operations in 1952. Historically, spent nuclear fuel from defense projects was reprocessed to separate reusable uranium from spent nuclear fuel. In 1992, the U.S. Department of Energy Idaho Operations Office (DOE-ID) discontinued reprocessing. The current mission for INTEC is to receive and temporarily store spent nuclear fuel and radioactive waste for future disposition, manage waste, and perform remedial actions.

Pending reprocessing, spent nuclear fuel was stored underwater in basins, including CPP-603A. By the year 2000, all inventoried spent nuclear fuel was removed from the CPP-603A underwater storage basins and placed in newer underwater or dry storage facilities at the INL. The inactive water treatment system used to maintain the quality of the CPP-603A basin water will be closed separately under the INL Voluntary Consent Order in accordance with the requirements of HWMA/RCRA (Idaho Code $§ 39-4401$ et seq.; 42 USC $\S 6901$ et seq.). VES-SFE-106, the waste tank system receiving and storing wastes from basin water treatment system, is also undergoing closure in accordance with the requirements of HWMA/RCRA (Idaho Code $\S 39-4401$ et seq.; 42 USC $\S 6901$ et seq.). The CPP-603A basins are no longer needed for fuel storage; however, they are still in use to provide shielding and either must be maintained so the basins do not present a threat to public or worker health and safety or they must be isolated from the environment. The DOE-ID needs to eliminate the risk associated with maintaining this facility and its associated processes because the environmental risk will increase as the facility ages. Therefore, the DOE-ID is initiating this non-time-critical removal action to reduce or eliminate the risks associated with maintaining this facility. This action does not prejudice the final end-state alternatives.

\subsubsection{Physical Facility}

The DOE-ID began construction of CPP-603 in the early 1950s, and the underwater storage basins began operation in 1952. The basins have been used to store spent nuclear fuel from the time they were placed in service and will become inactive through implementation of the Action Memorandum (DOE-ID 2005) for this removal action. The facility was constructed to seismic criteria, construction codes, and safety requirements of the early 1950s. In addition, the basins (which were constructed of reinforced concrete) have no secondary liners. Currently, the basins are maintained full of water to minimize exposure to the radionuclides associated with the debris in the basins as well as to radioactive contamination affixed to the basin floors and walls. 
The storage basins are reinforced concrete structures with most of their volume below grade. Each of the three basins and the Transfer Canal are filled with water. The combined volume of water in the storage basins and Transfer Canal is approximately 5.30E+06 L (1.40E+06 gal).

The North and Middle Basins are $17.5 \mathrm{~m}(57.5 \mathrm{ft})$ long, $11.4 \mathrm{~m}(37.5 \mathrm{ft})$ wide, and $6.4 \mathrm{~m}(21 \mathrm{ft})$ deep. Each of the basins is $1.28 \mathrm{E}+03 \mathrm{~m}^{3}\left(1.68+03 \mathrm{yd}^{3}\right)$ in volume. The basins and Transfer Canal are covered with fiberglass grating and a radiation shield consisting of lead plate sandwiched between aluminum plates. The shielding is present primarily for activity associated with historical spent fuel management and accumulation of a residue ring on the basins' and Transfer Canals' walls at the surface of the water. Concrete beams that are $0.3 \mathrm{~m}(1 \mathrm{ft})$ wide on $0.6-\mathrm{m}(2-\mathrm{ft})$ centers and support the grating and radiation shield. Similar concrete dividers are located on the bottom of the basins. The beams, concrete dividers, and other fixtures were designed to sustain the spent nuclear fuel in a safe configuration.

Spent nuclear fuel stored in the North and Middle Basins was suspended under water from monorails located approximately $3 \mathrm{~m}$ (8 ft) above the basin walls. Small, 4-cm (1.5-in.) -wide continuous slots in the grating under the track allowed the fuel to move to its storage location. The South Basin is an open basin, $12.8 \mathrm{~m}(42.0 \mathrm{ft}) \times 23.6 \mathrm{~m}(77.25 \mathrm{ft})$ in area and $6.4 \mathrm{~m}(21 \mathrm{ft})$ deep. The total volume of the South Basin is $1.93 \mathrm{E}+03 \mathrm{~m}^{3}\left(2.52 \mathrm{E}+03 \mathrm{yd}^{3}\right)$. Fuel was placed in the South Basin in aluminum or stainless-steel racks. The racks were accessed using a catwalk crane located above the basin. The racks have been removed from the basins. The South Basin contains three storage boxes. The $1 \times 1 \times 1.2-\mathrm{m}$ $(3 \times 3 \times 4$-ft), open-top carbon steel boxes contain miscellaneous cobalt-60 containing basin debris objects.

A $2.2 \times 61.0 \times 6.4-\mathrm{m}(7 \times 200 \times 21-\mathrm{ft})$ Transfer Canal connects the three storage basins. The total volume of the Transfer Canal is $8.6 \mathrm{E}+02 \mathrm{~m}^{3}\left(1.09 \mathrm{E}+03 \mathrm{yd}^{3}\right)$. A floor grating overlaid with lead-plate shielding covers the Transfer Canal. The monorail track extends overhead on both sides of the Transfer Canal. In addition, continuous slots are located in the Transfer Canal's grating to facilitate movement of the fuel to the assigned storage basin.

The floors of the storage basins were covered with a layer of sediment. The sediment (which is referred to in this document as sludge) consists of desert sand, dust, precipitated corrosion products, and residuals from past fuel-cutting operations.

This non-time-critical removal action, which is an interim action, applies to the CPP-603A basin system, including the Fuel Element Cutting Facility's Transfer Tunnel, the overflow pit, the North and South transfer stations, and the Transfer Canal. Deactivation, decontamination, and decommissioning of the other currently unused portions of CPP-603A will be coordinated with the final deactivation, decontamination, and decommissioning of the CPP-603 Complex. The CPP-603B (Irradiated Fuel Storage Facility) is expected to remain active until approximately 2035. Currently, the basin water treatment system is being closed under the Voluntary Consent Order in accordance with the requirements of HWMA/RCRA (Idaho Code $\S 39-4401$ et seq.; 42 USC $\S 6901$ et seq.). Preparation to close the VESSFE-106 waste tank system in accordance with HWMA/RCRA requirements is also underway.

\subsection{Contaminants of Concern}

In 1993, sludge was sampled from the South Basin. In addition, sludge samples were taken from distributed locations throughout all three basins in 1994. Analyses from these sampling activities indicated the presence of silicon, aluminum, and iron as the major constituents. The high percentage of silicon and aluminum seems to indicate that a large portion of the sludge is soil particulate that has entered the building as a result of wind and weather events. Sample analyses did not indicate a significant amount of neutron poisons such as boron, cadmium, or chlorine. However, sampling results indicated the 
presence of cadmium above the HWMA/RCRA regulatory level of $1 \mathrm{mg} / \mathrm{L}$. Uranium-235 content and the major elements essentially determined the neutron reactivity. The Engineering Evaluation/Cost Analysis (DOE-ID 2004) estimates that approximately $6.96 \mathrm{~kg} \pm 3.22(15.34 \mathrm{lb})$ of U-235 that is less than $0.125 \mathrm{in}$. in diameter and that $3.8 \mathrm{~kg}(8.38 \mathrm{lb})$ of $\mathrm{U}-235$ that is greater than $0.125 \mathrm{in}$. in diameter are contained in the sludge and distributed over the basin floor area.

In 1997, additional samples were collected of the basin sediments. Cadmium, chromium, lead, and barium were detected in one sample from the South Basin. This indicates that a significant contribution to the basin sludge originates from the spent nuclear fuel previously stored there. In addition, elevated concentrations of cadmium may indicate a higher neutron flux in some areas.

Extensive radiological surveying has been conducted throughout the CPP-603A basin facility. Basin floor surveys of the North Basin detected levels ranging from 100 to $900 \mathrm{mR} / \mathrm{hr}$. Basin floor surveys of the Middle Basin detected levels ranging from $100 \mathrm{mR} / \mathrm{hr}$ to $10.2 \mathrm{R} / \mathrm{hr}$ near the southeast corner. Basin floor surveys of the South Basin detected radiation levels from 100 to $600 \mathrm{mR} / \mathrm{hr}$. A floor survey of the Transfer Canal detected radiation levels ranging from $100 \mathrm{mR} / \mathrm{hr}$ to $32 \mathrm{R} / \mathrm{hr}$ near the south end of the canal. Generally, the radiation levels in the basins are approximately 5 to $15 \mathrm{mR} / \mathrm{hr}$ on the top of the basin and 100 to $150 \mathrm{mR} / \mathrm{hr}$ at the scum ring around the basin walls.

The building contains asbestos materials in the form of transite siding in the roofing and walls. The exterior walls consist of an outer layer of transite siding and an inner layer of transite siding with fiberglass insulation in between. Low levels of radiological contamination also are in the painted carbon steel superstructure and the interior transite siding. Past surveys have found high levels of contamination on superstructure surfaces. A false ceiling over the North and Middle Basins also is made of transite panels. In addition, the insulation on the steam and condensate piping throughout the facility contains asbestos.

Lead shielding is present throughout the CPP-603A basin facility. The deck plates over the North and Middle Basins and the Transfer Canal contain a 0.64- $\mathrm{cm}(0.25-\mathrm{in}$.) lead plate riveted between two aluminum plates. In addition, shielded areas adjacent to the water treatment areas and the Fuel Element Cutting Facility contain lead blankets and lead bricks. Lead also was found on the transite panel fastener system. Lead washers were used to hold the transite walls together.

Further characterization activities will be ongoing during the removal action at the CPP-603A basin facility. Additional hazardous materials and radionuclide contamination may be located or detected.

\section{REMOVAL ACTION WORK ACTIVITIES}

The actions addressed in this Removal Action Work Plan are consistent with Alternative 3 described in the Engineering Evaluation/Cost Analysis (DOE-ID 2004). The sludge in the basins will be removed and treated in accordance with HWMA/RCRA requirements (Idaho Code $\S 39-4401$ et seq.; 42 USC $\S 6901$ et seq.) prior to the removal action activities. The non-time-critical removal action includes removing SHADO 1 which was completed in March 2005; removing, treating, and disposing of the basin water; and filling the basins with grout/CLSM. The tasks to be accomplished at the removal action site are described below, including a brief discussion of the sludge removal, treatment, and disposal to be accomplished in accordance with HWMA/RCRA requirements.

Basin water will be removed while the basins are being filled with grout/CLSM. The water will be pumped to the ICDF evaporation ponds and evaporated. The highly contaminated scum ring on the basin walls will not be exposed during water removal and grout/CLSM pumping operations. The grout/CLSM 
will provide shielding for the radioactive contamination embedded in the basin floor and walls, thereby minimizing possible migration and airborne contamination.

SHADO 1, a small high-activity debris object, has been removed and relocated to a facility designed to manage the high levels of radiation. Removal and relocation of SHADO 1 was completed in March 2005. Debris objects containing radioactive cobalt have been consolidated in the South Basin and will be encapsulated in the grout/CLSM. The position of the debris objects has been recorded to facilitate future removal, if necessary. The final decontamination and disposition of the basin structure will be evaluated when the entire CPP-603 Complex is taken out of service. The implementation and completion dates for those activities will be negotiated with the DEQ.

DOE-ID has prepared a characterization plan (Characterization Plan for Soils Around Drain Line PLA-100115 [DOE-ID-11260]) to conduct soil sampling and analysis around the failed drain line (3 1/2 inch PLA-100115). This action is a commitment made in the HWMA/RCRA Less Than 90-day Generator Closure Report for the VES-SFE-126 (INEEL 2000). When the water is removed from the basins and the threat to the integrity of the basin is mitigated, the characterization plan specifying methods for determining the nature and extent of contamination will be implemented as a separate action.

The DOE-ID compared the alternatives described in Section 5 of the Engineering Evaluation/Cost Analysis (DOE-ID 2004) and prefered Alternative 3 because it complies with regulations and is cost effective. This action was selected because:

- $\quad$ Removal of the water from the basins is the most effective action to eliminate the threat of a release to the environment.

- This removal action is consistent with the Final Record of Decision (DOE-ID 1999). As such, it supports the overall remediation at WAG 3.

- $\quad$ Placing grout/CLSM in the basins implements DOE-ID's management policy for controlling worker radiation exposure to levels as low as reasonably achievable (ALARA) by minimizing exposure to the highly contaminated scum line on the basin walls and encapsulating the nonuranium-235 containing debris and rubbish on the bottom of the basins.

- This removal action is an interim action and does not prejudice the future end-state alternative.

Activities will be performed using currently accepted practices and standard operating procedures.

\subsection{Sludge Removal, Treatment, and Disposal}

The CPP-603A basins contained an estimated 49,300 kg of sludge. The sludge is composed of desert sand, dust, precipitated corrosion products, and metal particles from past cutting operations. The sediment also is known to contain radioactive contamination and hazardous constituents, including cadmium, lead, and uranium-235. A decision was made to manage the sludge in accordance with the requirements of the HWMA/RCRA (Idaho Code $\S 39-4401$ et seq.; 42 USC $\S 6901$ et seq.). The HWMA/RCRA regulations under 40 Code of Federal Regulations (CFR) 268.7(a)(5) and 40 CFR 262.34 allow a generator of hazardous or mixed waste to treat waste within 90 days without having a permit as long as certain guidelines are followed. Sludge removal, treatment, and disposal were conducted under a subcontract issued to Duratek Federal Services, Inc. The sludge from the CPP-603A basins was removed and treated prior to implementation of dewatering and grout placement activities. Removal of the sludge occurred while the basins remain in service. The sludge was removed and treated to meet RCRA Land Disposal Restriction standards and the Radioactive Waste Management Complex (RWMC) waste 
acceptance (WAC) criteria. The sludge was treated to meet Universal Treatment Standards in 40 CFR 268.48 under HWMA/RCRA authority.

This overview outlines the activities required to remove, treat, characterize, package, and transfer sludge from the CPP-603A basins to an approved disposal facility. The initial step was preparation of a statistically defensible process control program to ensure that optimal solidification is achieved for all waste types. A sampling approach designed to collect sample matrix from randomly selected areas in the basins in sufficient quantities to ensure the data yield statistically valid representative data was employed. Data decisions were based on calculations provided in SW-846 Chapter 9 (EPA 2002) to ensure that the data adequately represent a $90 \%$ certainty that $90 \%$ of the waste falls below the Universal Treatment Standards. The tests and calculations determined the required amounts of additives needed to develop a "recipe" for the full-scale treatment process. The process treated the sludge to meet Universal Treatment Standard requirements and statistically demonstrated that the resulting waste product meets the RWMC's WAC. Once the process control program was developed and confirmed using a surrogate waste and calculations, the sludge was removed from the North, South, and Middle Basins; North and South transfer stations; and Transfer Canal by vacuuming the material from the floors and horizontal surfaces. This activity was accomplished by underwater nuclear divers and from the surface of the basins using longreach tools, depending on personnel exposure and ALARA considerations. The sludge was pumped from the vacuum unit and passed through a radiation monitor to protect workers from inadvertent exposure to highly radioactive material. It was then pumped to approximately 1,200-gal, high-integrity containers (HICs) where excess water was removed by filtration and returned to the basins. The dewatered sludge was stabilized using the treatment process developed in a treatability study by mixing specific amounts of grout and additives designed to meet HWMA/RCRA Land Disposal Restriction requirements. Samples of the treated sludge were collected from the HICs before the grout mixture solidified. These samples were analyzed to measure the fissile material content of each HIC, for Safeguards and Security purposes, for transfer to RWMC. Additionally, randomly selected samples of the treated sludge were analyzed to confirm that the treatment was effective. The treated waste was allowed to cure in the HICs and then stored pending transport to the RWMC. Treatment occurred under a generator treatment plan in batches, and all batches of waste were treated within required 90-day periods.

The removal, treatment, and disposal of the sludge was completed in preparation for the CERCLA removal action at the CPP-603 facility. The primary objective was to remove the sludge from the basin facility, thereby reducing the environmental hazard. This effort was performed in accordance with the activities described in the Engineering Evaluation/Cost Analysis (DOE-ID 2004), in compliance with HWMA/RCRA standards, and as agreed upon by the DOE, the State of Idaho Department of Environmental Quality, and the U.S. Environmental Protection Agency (EPA), Region 10. Once the sludge was removed from the basins and successfully treated, it will be temporarily stored until the stabilized waste was transported to the RWMC for disposal.

\subsection{Removal of the Small High-Activity Debris Object (SHADO 1)}

The SHADO 1 identified in the South Basin during basin scanning has been removed from the basin under this Removal Action Work Plan. The SHADO 1 was described in detail in the Engineering Evaluation/Cost Analysis (DOE-ID 2004). The sequence of events implemented by INTEC Operations personnel to manage SHADO 1 was as follows:

- While the SHADO 1 was still in the South Basin, operations personnel manually transferred it using long-reach tools to a basket suitable for dry storage in the Irradiated Fuel Storage Facility (IFSF). 
- $\quad$ The basket was transferred to a transport and interim storage package.

- $\quad$ The transport-storage package with the basket containing SHADO 1 was removed from the CPP-603 South Basin.

- $\quad$ The SHADO 1 object was transported to the IFSF according to the IFSF fuel transfer schedule.

- $\quad$ The SHADO 1 was placed into an IFSF fuel storage canister with similar material and stored in the IFSF for the foreseeable future.

At least two additional fissile material objects were located and identified during sludge removal activities. The objects were isolated in the South Basin until sludge removal was completed in that area. Prior to placement of grout in the basins, the objects were removed and managed in the same manner as the SHADO 1 object.

\subsection{Consolidation and Location of Cobalt-60 Containing Debris}

Before water removal and grout/CLSM placement in the basins, the discrete, high-activity cobalt-60 containing metal pieces identified were consolidated in the three existing "hot waste boxes" in the South Basin and the location was noted for future reference. The "hot waste boxes" are located $20 \mathrm{ft}$ from the east wall with the three "hot waste boxes" situated from 8 to $12 \mathrm{ft}$ from the north wall of the South Basin. The debris objects will be encapsulated and shielded by the grout/CLSM placed in the basins. High activity (through activation) objects have been found within the basins. The primary contaminant is cobalt- 60 . Cobalt- 60 decays rapidly and has a half-life of 5.27 years. The total amount of cobalt-60 in all debris objects will decay to approximately $19.5 \mathrm{Ci}$ by 2035 , when operations in the CPP603 Complex are expected to end. If the end state selected for the CPP-603 Complex includes removal of the basins and the debris objects, the location of the objects has been recorded, as described above, to allow workers to readily locate them for removal in the future if deemed necessary.

\subsection{Basin Water Removal, Treatment, and Disposal and Filling the Basins with Grout/CLSM}

Prior to water removal and grout placement in the basins, a concern was identified from a lessons learned from similar grout placement activities occurring at the Hanford site. Pieces of aluminum metal on the floor of the basins may react with the caustic grout to generate hydrogen gas. In some of the CPP603 basin locations, this hydrogen gas might be able to concentrate and reach the lower flammability limit of $4 \%$. Prior to any grout addition to the basins, this potential problem will be evaluated and mitigated. Possible mitigation measures include removing some of the aluminum metal from the basins, relocating the aluminum to a part of the basin that allows free venting of the gas, or removing overhead obstructions to allow the hydrogen gas to dissipate and prevent accumulation of dangerous concentration of gas.

\subsubsection{Grout/CLSM Mixture Design}

The basins and associated transfer channels and canals will be filled with a pumpable, self-leveling grout and/or controlled low strength material (CLSM) mixture designed to minimize the effects of washout and shrinkage. The grout/CLSM mixture will be capable of being placed underwater. The cured grout/CLSM will be capable of being removed from the basins, if necessary, utilizing conventional excavating equipment. 


\subsubsection{Grout/CLSM Placement System}

The grout/CLSM placement system and the grout/CLSM placement plan are designed to allow the grout/CLSM to fill the underwater basin system volume. Grout/CLSM will be placed in the designated locations throughout the basins through PVC tremie pipes. As grout/CLSM is placed on the bottom of the basin, the grout/CLSM will rise above the end of the tremie pipe until that specific pour is completed. To raise the tremie pipe to the correct level for the next pour, a 2-foot section of the tremie pipe can be disconnected from the top of the assembly and abandoned in the grout/CLSM. Grout/CLSM will be place at approximately three locations each in the North and Middle Basins, five locations in the South Basin, and nine placement locations across the transfer stations and canal. Additional grout/CLSM placement locations may be added during grout/CLSM placement to achieve uniform coverage of the basins.

2.4.2.1 Grout/CLSM Batch Plant. The grout/CLSM material will be supplied from either an onsite or an off-site grout/CLSM batch plant. A subcontract is being put in place to supply concrete, grout, and CLSM to multiple INTEC projects. As part of this subcontract, an on-site grout/CLSM plant may be constructed east of CPP-603 near the old Coal Fired Steam Plant. The grout/CLSM batching facility will have the ability to produce the CPP-603A Basin specific grout/CLSM "recipe" at a rate of at least $40 \mathrm{yd}^{3}$ per hour during the grout/CLSM placement period. Daily placement volumes are estimated to be between 85 and $140 \mathrm{yd}^{3} /$ day and will be delivered to the CPP-603A basins grout/CLSM pump stations in concrete mixing trucks. Approximately 700 truckloads will be required to fill the basin system. The concrete mixing trucks will deliver the specified grout/CLSM mixture to a hopper on the grout pump.

An area located near the grout pump stations will be identified for cement truck clean-out. Excess grout/CLSM and flush water from the cleaning will be temporarily contained until grout/CLSM placement is completed. After the waste material held in the containment has solidified, it will be collected and removed for proper disposal.

2.4.2.2 Grout/CLSM Delivery System. Pre-mixed grout/CLSM will be pumped to the approximately 20 grout/CLSM placement locations throughout the basin system from a grout pump that will be located in one of two areas outside of CPP-603, as necessary. As shown in Figure 1, the grout pump is proposed to be located outside of CPP-603 in the open area between the structures housing the North and Middle Basins to supply grout/CLSM to the placement locations in the North and Middle Basins and the north end of the Transfer Canal. To supply the placement locations in the South Basin, South Transfer Station, and south end of the Transfer Canal, the same grout pump will be re-located just north of the east roll-up door to the East-West truck bay. 


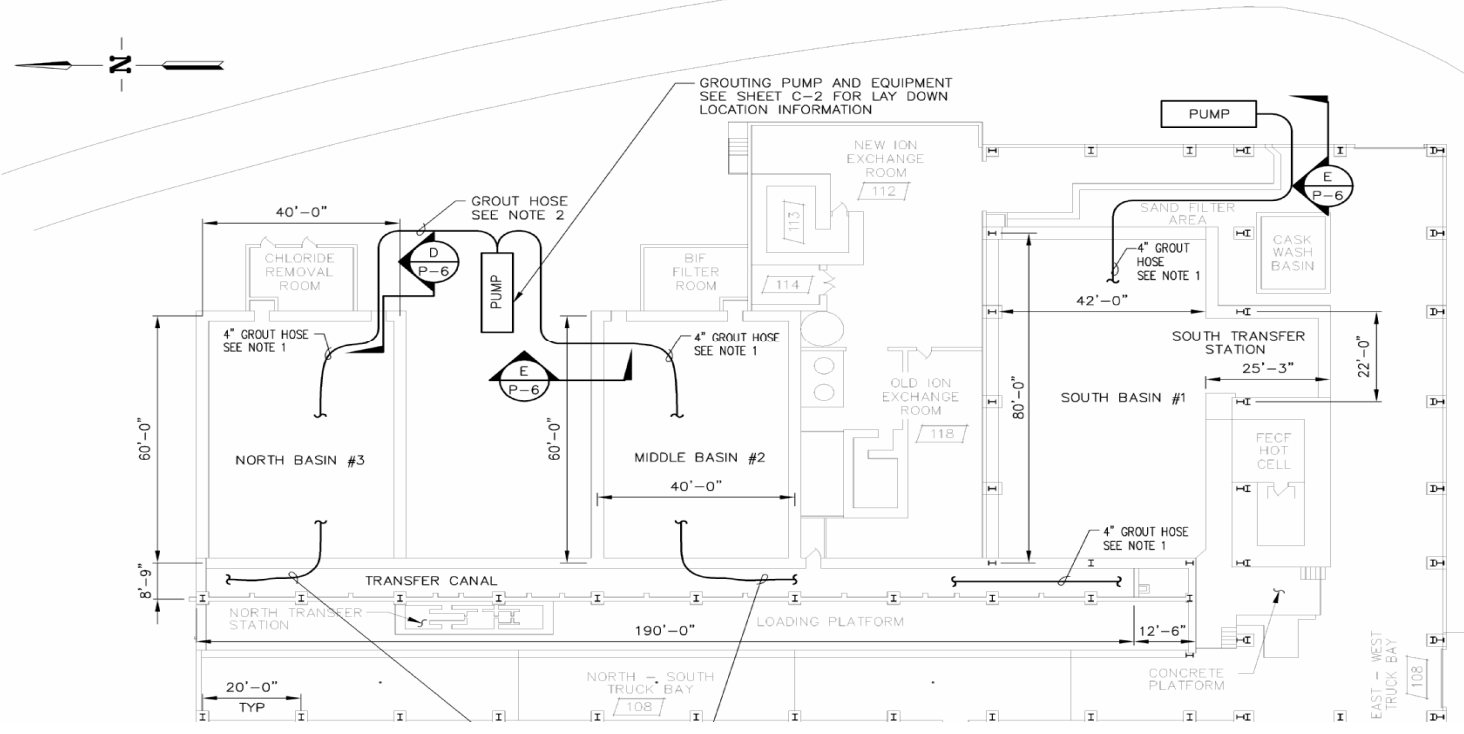

Figure 1. Grout/CLSM Piping Location Plan.

The grout pump will be connected to the grout/CLSM placement tremie pipe by a flexible grout hose. The grout placement hose will be field routed from the pumping equipment and connected to one of three of the proposed pipe spools depicted in Figure 2. required to penetrate the walls of the facility. A rupture disc outlet pipe will be included in the system to protect personnel and equipment in case of system over-pressurization relief. Grout/CLSM will be pumped to the grout/CLSM placement locations at a rate of approximately $40 \mathrm{yd}^{3} / \mathrm{hr}$.

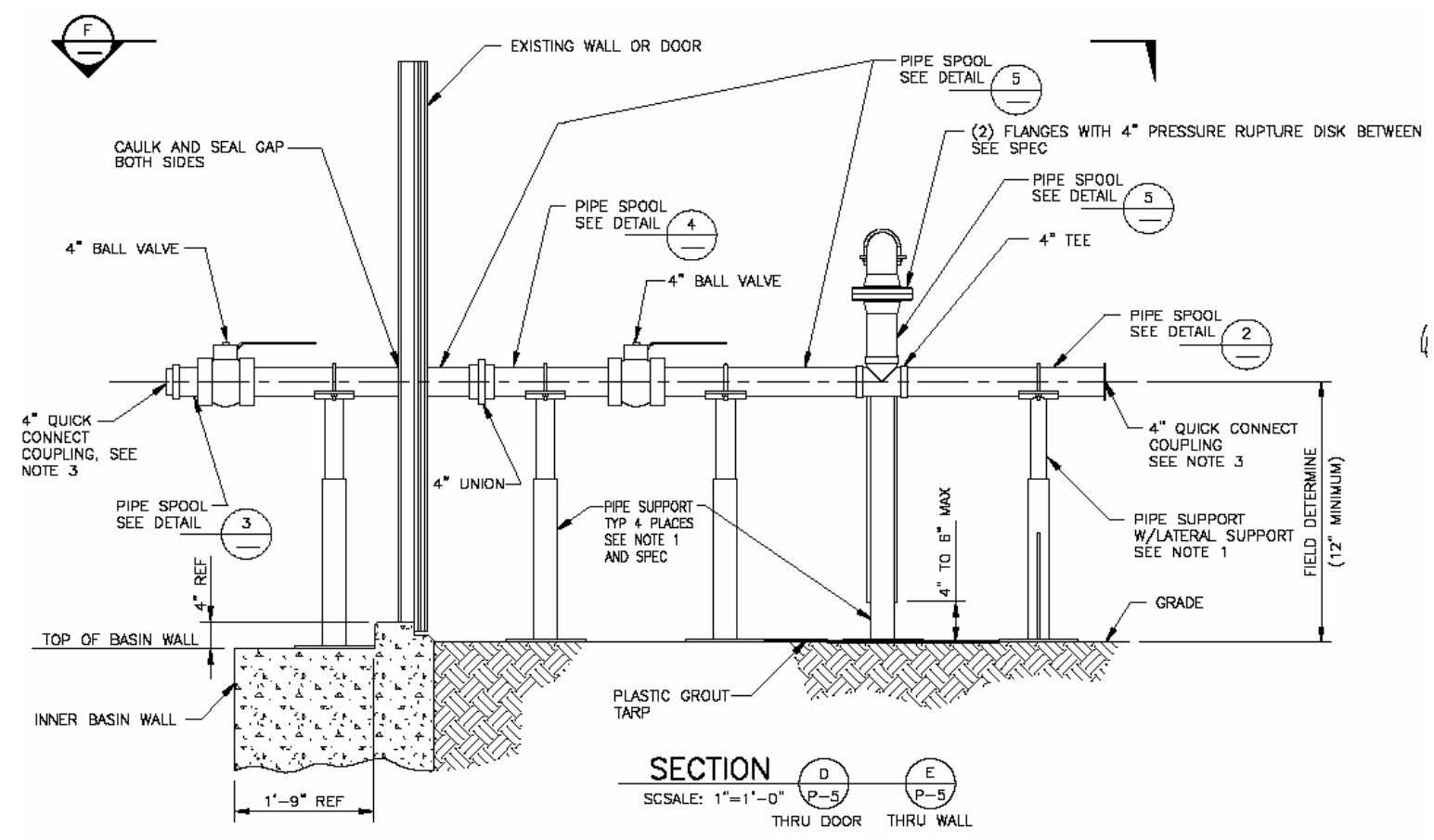

Figure 2. Facility wall penetration piping. 
2.4.2.3 Grout/CLSM Volumes. The estimated volumes of grout/CLSM need to fill the various areas in the CPP-603A basin are described in Table 1.

Table 1. CPP-603A Basins Grout/CLSM Volumes.

\begin{tabular}{lccccc}
\hline \multicolumn{1}{c}{ Area to be Filled } & $\begin{array}{c}\text { Width } \\
(\mathrm{ft}) /(\mathrm{m})\end{array}$ & $\begin{array}{c}\text { Length } \\
(\mathrm{ft}) /(\mathrm{m})\end{array}$ & $\begin{array}{c}\text { Height } \\
(\mathrm{ft}) /(\mathrm{m})\end{array}$ & $\begin{array}{c}\text { Grout/CLSM* } \\
\left(\mathrm{yd}^{3}\right) /\left(\mathrm{m}^{3}\right)\end{array}$ & $\begin{array}{c}\text { Water* } \\
\left(\mathrm{gal}^{*}\right)\end{array}$ \\
\hline North & $37.50 / 11.4$ & $57.50 / 17.5$ & $21 / 6.4$ & $1,677 / 1,282$ & 339,000 \\
Middle & $37.50 / 11.4$ & $57.50 / 17.5$ & $21 / 6.4$ & $1,677 / 1,282$ & 339,000 \\
South & $42.00 / 12.8$ & $77.25 / 23.6$ & $21 / 6.4$ & $2,524 / 1,930$ & 510,000 \\
South Transfer Station & $22.75 / 6.9$ & $19.50 / 5.9$ & $21 / 6.4$ & $345 / 264$ & 70,000 \\
Transfer Tunnel & $6.5 / 2.0$ & $16 / 4.9$ & $21 / 6.4$ & $81 / 63$ & 16,000 \\
Transfer Canal & $7 / 2.2$ & $200 / 61.0$ & $21 / 6.4$ & $1089 / 859$ & 220,000 \\
North Transfer Station & $5.67 / 1.7$ & $28 / 8.5$ & $21 / 6.4$ & $123 / 94$ & 25,000 \\
$\begin{array}{l}\text { Total } \\
\text { (approximate) }\end{array}$ & & & $7,516 / 5,774$ & $1,519,000$ \\
* These volume estimates do not exclude the volume already filled by beams and columns within the basin system.
\end{tabular}

2.4.2.4 Grout/CLSM Placement. The flow of grout/CLSM between the basins and the Transfer Canal through the three existing head gates will be controlled by placing $1 \mathrm{ft}$ or $2 \mathrm{ft}$ tall by $3 \mathrm{ft}-4$ inch wide grout dam panels in the head gates as needed. Figure 3 and 4 provide the proposed patterns that will allow the grout/CLSM to fill the underwater basin system volume. Additional placement locations may be added at the discretion of the operators. The grout/CLSM will be placed initially in small lifts of a few inches to one foot depth to optimize capture of any residual sludge. Later lifts will be up to four feet thick. The basins and Transfer Canal and other underwater cavities will be filled to within 4 inch of the top of the basin walls while the water level is maintained between $19 \mathrm{ft}-0$ inch and $19 \mathrm{ft}-11$ inch during grout/CLSM placement activities. The grout/CLSM mixture will be designed in such way as to allow the mixture to flow into and fill the void spaces in the three "hot waste boxes" located in the South Basin. The cobalt- 60 contaminated debris consolidated in the boxes will thus be stabilized on the bottom of the South Basin.

The basin water has enough radioactive particulates that if it were allowed to dry out, a significant potential for airborne contamination exists. To minimize this treat, the final layers of grout will be place in such a manner that the majority of water will be displaced and pushed in the direction of the pump out location. This method of placement should minimize the amount of standing water left behind to evaporate. This will be evaluated by project and facility personnel as grouting progresses. Any grout/CLSM surfaces that come in contact with the contaminated basin water and are exposed to air could increase airborne contamination levels as the surfaces dry out. These surfaces will be dealt with as directed by project, facility and radiological control personnel, which could include coating the surfaces with a fixative layer applied to the grouted surfaces. Periodic radiological surveys will be performed to assess the conditions of the grouted surfaces until such time that the final cap can be placed. 


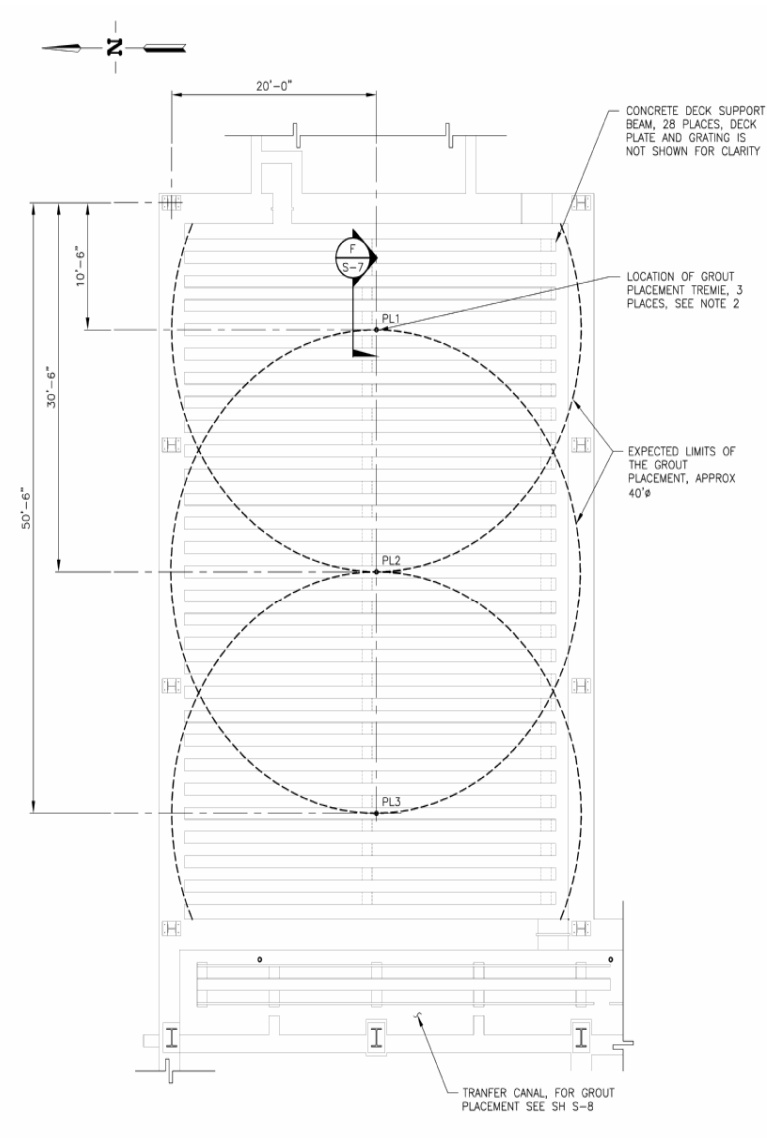

NORTH BASIN \#3 GROUT PLACEMENT PLAN

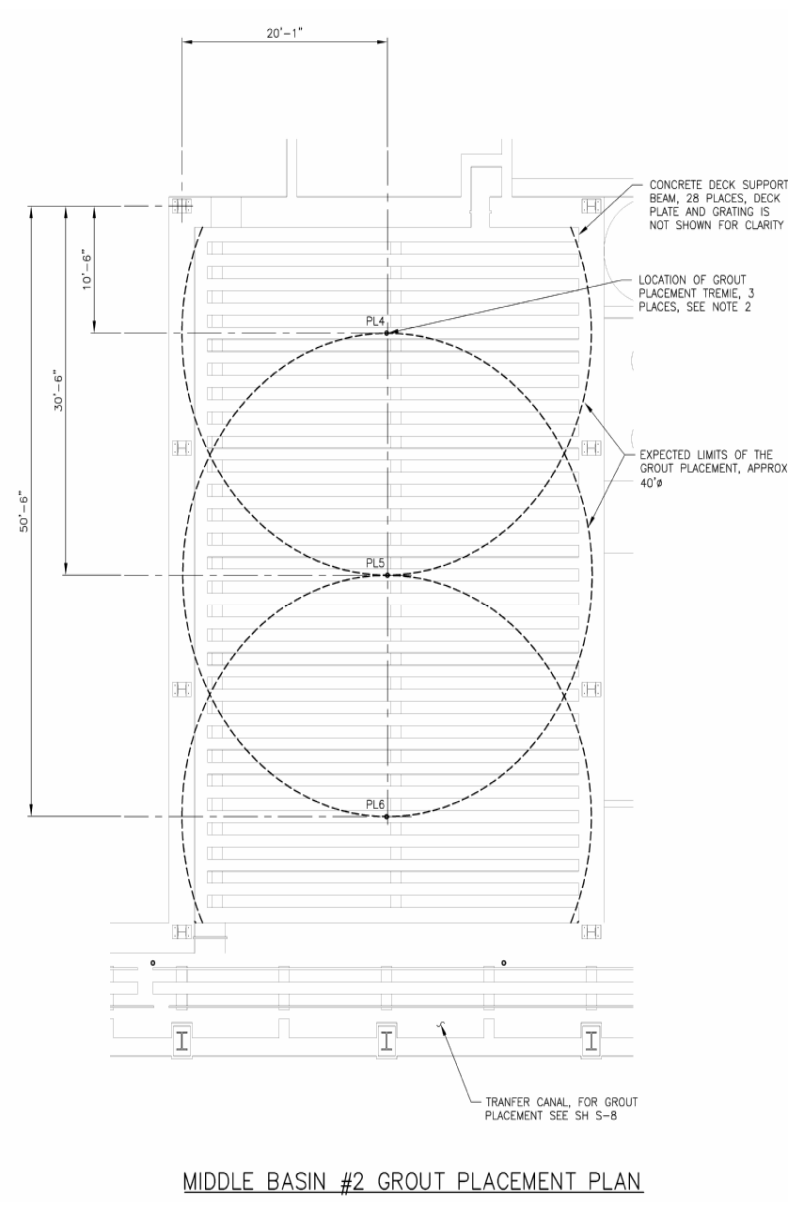

NOTFS
2. THE GROUT PLACEMENT PATTERN IS SHOWN FOR A GUIDE. THE INTENT OF THE PATTERN SHOWN IS TO ALLOW THE GROUT TO BE PLACED IN SUCH A WAY AS TO ALLOW APPROXIMATELY UNIFORM COVERAGE OF THE ENTIRE BASIN. ADDITIONAL PLACEMENT LOCATIONS MAY BE ADDED AT THE DISCRETION OF THE SUBCONTRACTOR TO ACHIEVE UNIFORM COVERAGE OF THE BASIN.

Figure 3. Proposed North and Middle Basins Grout/CLSM Placement Plan. 


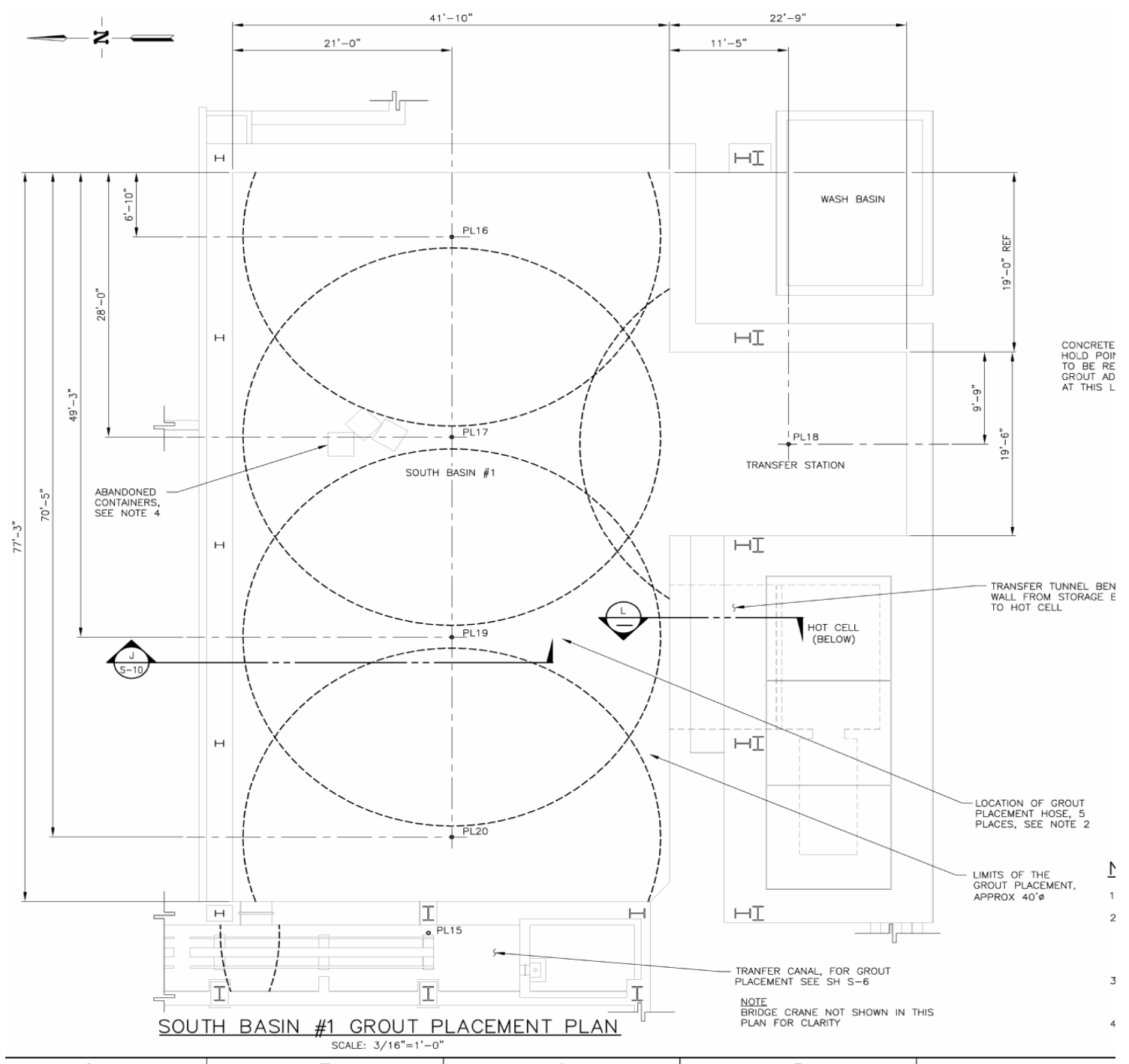

2. THE CONCRETE/GROUT PLACEMENT PATTERN IS SHOWN FOR A GUIDE. THE INTENT OF THE PATTERN SHOWN IS TO ALLOW THE GROUT TO BE PLACED IN SUCH A WAY AS TO ALLOW APPROXIMATELY UNIFORM COVERAGE OF THE ENTIRE BASIN. ADDITIONAL POUR LOCATIONS MAY BE ADDED AT THE DISCRETION OF THE SUBCONTRACTOR TO ACHIEVE UNIFORM COVERAGE OF THE BASIN.

Figure 4. Proposed South Basin Grout/CLSM Placement Plan.

2.4.2.4.1 Method for Grout Placement-In the North and Middle Basins and Transfer Canal, it will be necessary to remove 2 of the shield deck plates at each of the grout/CLSM placement locations to provide access for the grouting process. The supporting fiberglass grating will remain in place and will be cut as required to allow installation of a new placement plate and sleeve. Figure 5 depicts the typical grout/CLSM placement configuration to be utilized in the North and Middle Basin and Transfer Canal. Figure 6 depicts a typical grout/CLSM placement configuration employed in the South Basin.

Three grout/CLSM placement locations will be on the centerline of the North and Middle Basins on approximately $20 \mathrm{ft}$ centers. Additional grout/CLSM placement location may become necessary depending on information gained from the process mock-up. The grout hose from the grout pump will 
connect to a quick disconnect coupling on the elbow attached to the pipe assembly that passes through the new deck plates leading to the PVC tremie pipe.

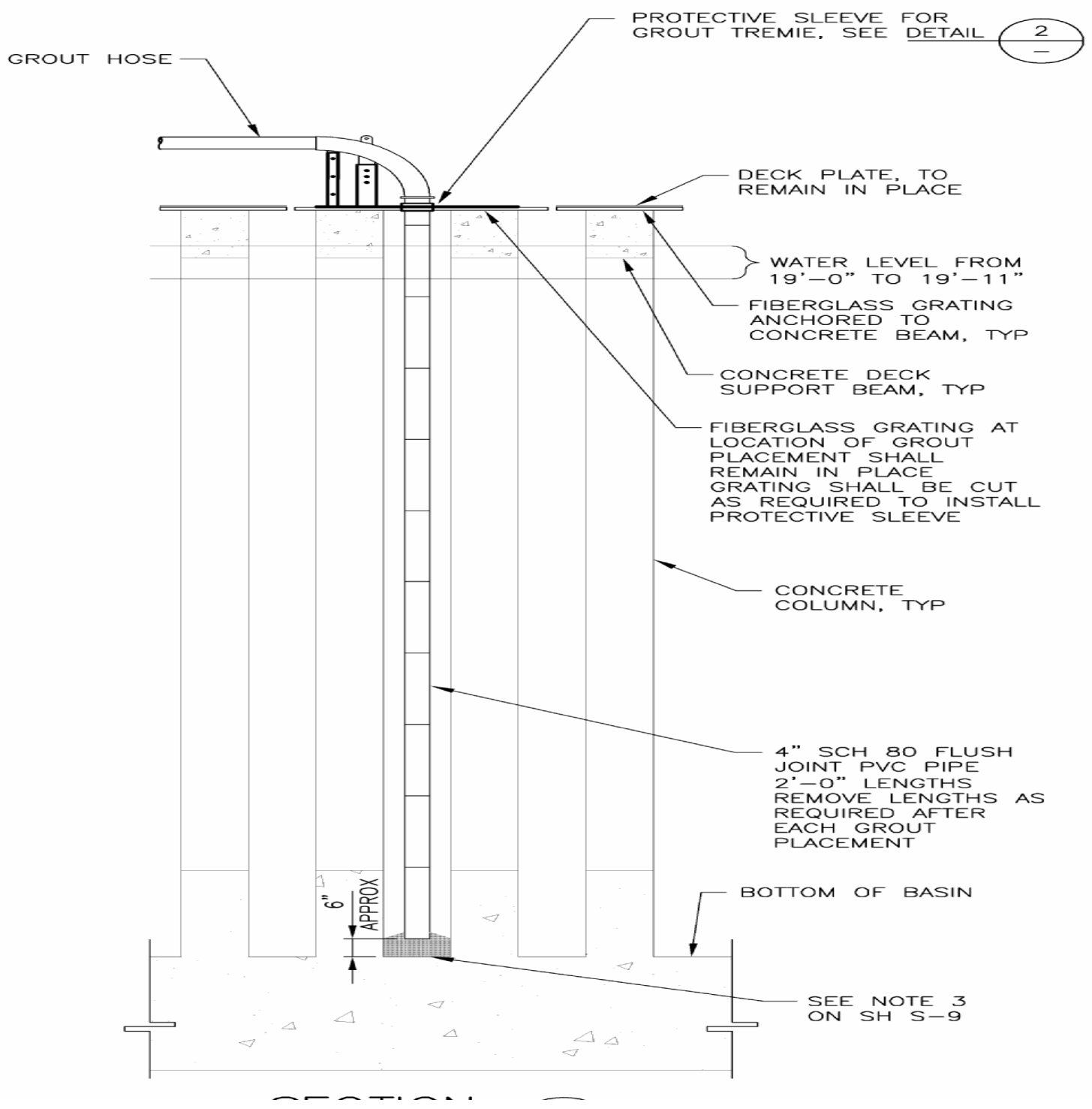

3. TAKE MEASURES TO ENSURE WATER FROM THE BASIN IS NOT PUSHED OVER THE HOT CELL PARAPET. THIS MAY BE ACCOMPLISHED BY MONITORING THE WATER LEVEL WITH RESPECT TO THE HOT CELL PARAPET DURING THE GROUT PLACEMENT IN THE VICINITY OF THE TRANSFER TUNNEL.

Figure 5. Typical North and Middle Basins Grout/CLSM Placement. 


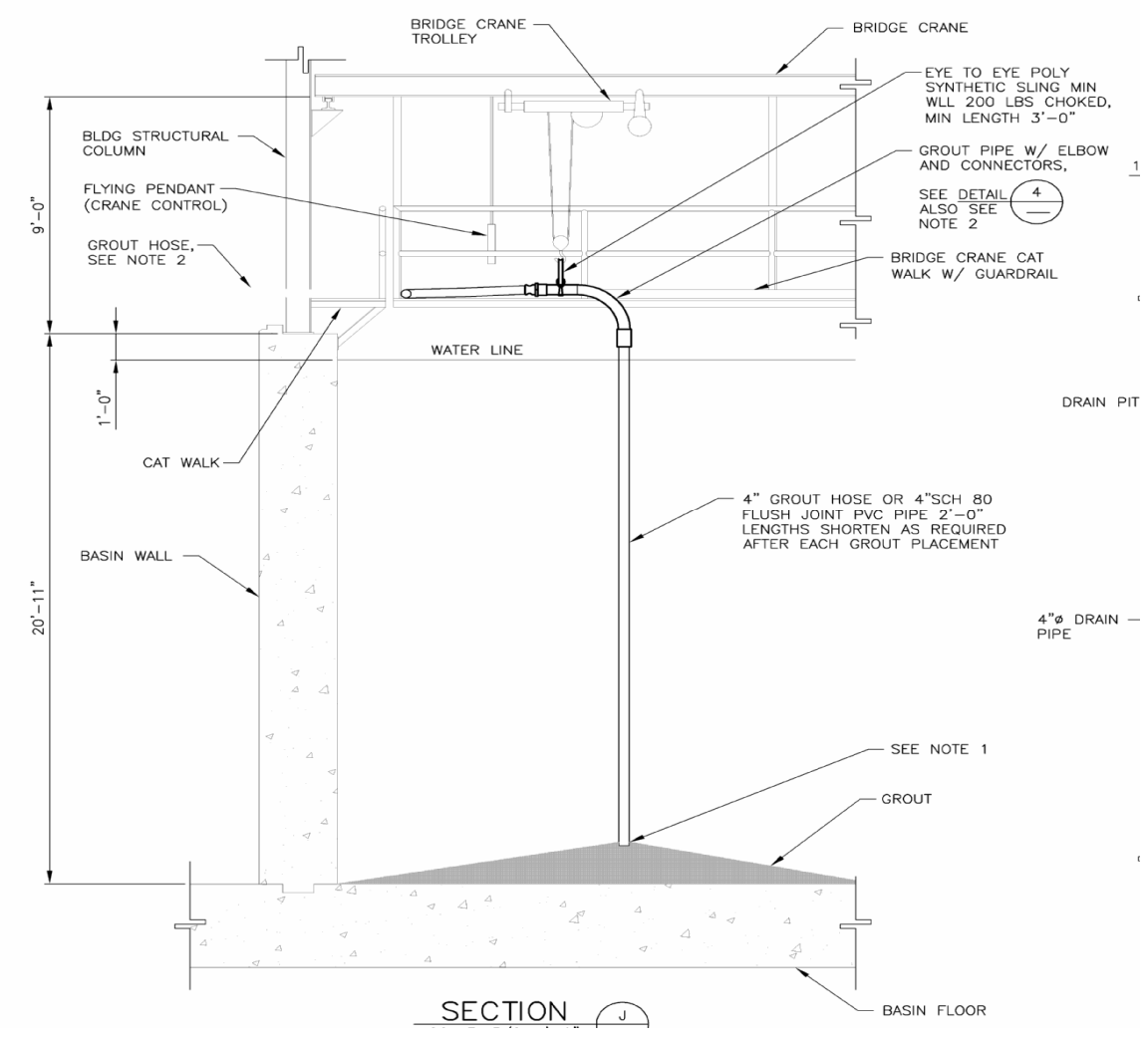

1. OUTLET NOZZLE TO REMAIN SUBMERGED IN FRESH CONCRETE/GROUT DURING PLACEMENT ACTIVITIES. RAISE AND LOWER CONCRETE/GROUT HOSE AS REQUIRED.

Figure 6. Typical South Basin Grout/CLSM Placement.

Because there are no shield deck plates in the South Basin, the grout hose, which connects to the grout pipe with an elbow and connections, will be suspended from the bridge crane from a sling. The PVC tremie pipe will be suspended from the elbow and operated in the same manner as the tremie pipes in the other basins so the outlet nozzle remains submerged in fresh grout/CLSM during placement. The grout hose may be placed on the bridge crane cat walk for placing the grout/CLSM if it is advantageous to eliminate the use of the pipe/elbow and crane hoist.

2.4.2.4.2 Transfer Tunnel Grout/CLSM Placement-A specially designed grout pipe system will be constructed and used in the Fuel Element Cutting Facility (FECF) "Hot Cell" to allow placement of grout/CLSM in the FECF Transfer Tunnel. The Transfer Tunnel will be accessed through a hatch above the "hot cell". As shown in Figure 7, the grout/CLSM level in the "hot cell" will be allowed to rise from the South Basin placement locations to a hold point above the bottom of the wall separating the Transfer Tunnel from the South Basin. After the grout/CLSM from the South Basin placements have reached the hold point and allowed to solidify, water in the Transfer Tunnel above the hold point will be removed and grout/CLSM will be placed from above through the hatchway utilizing specially designed hose assemblies. To ensure that basin water is not pushed over the hot cell parapet, the water level in the Transfer Tunnel will be monitored with respect to the hot cell parapet during grout/CLSM placement in the vicinity of the Transfer Tunnel. 


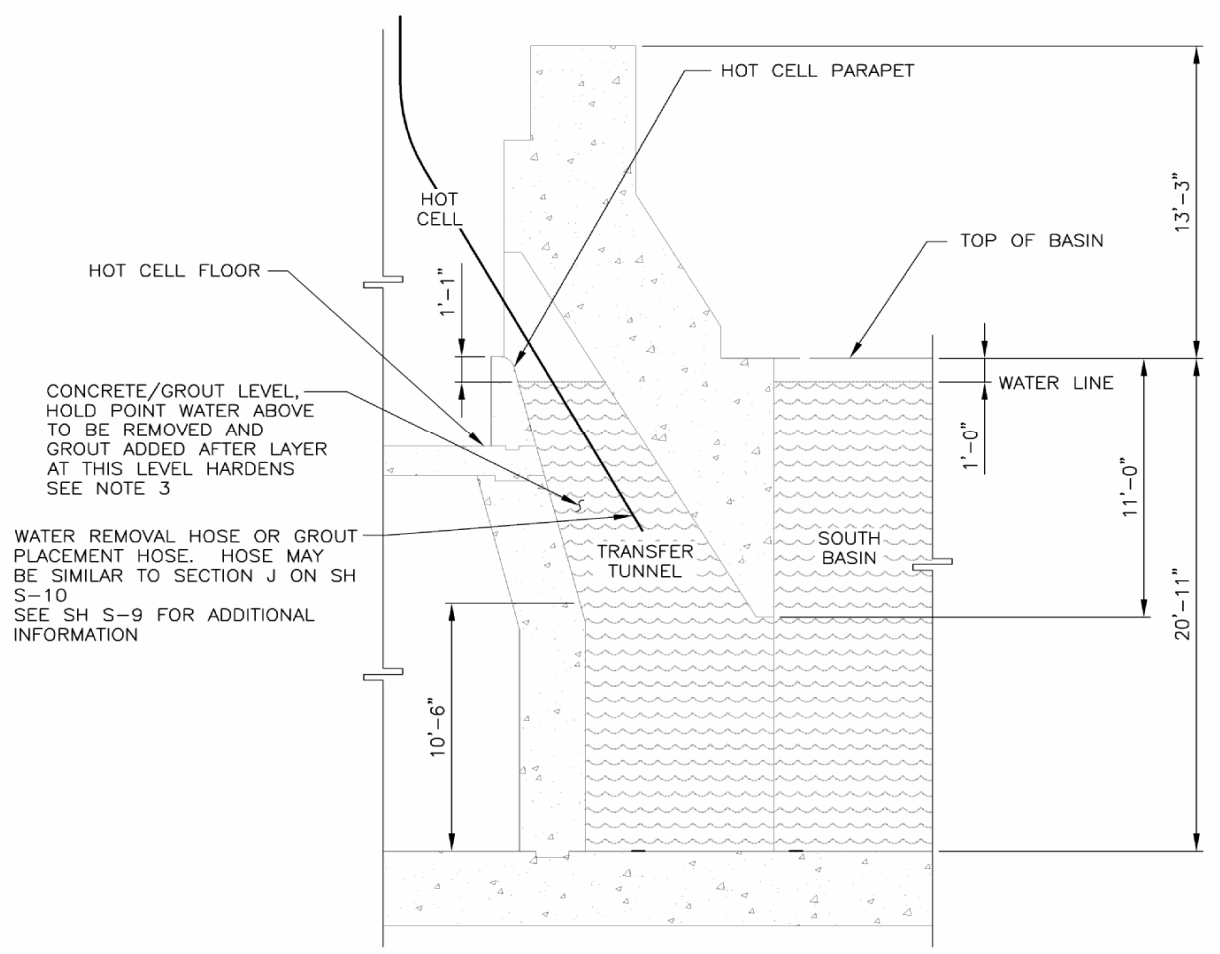

3. TAKE MEASURES TO ENSURE WATER FROM THE BASIN IS NOT PUSHED OVER THE HOT CELL PARAPET. THIS MAY BE ACCOMPLISHED BY MONITORING THE WATER LEVEL WITH RESPECT TO THE HOT CELL PARAPET DURING THE GROUT PLACEMENT IN THE VICINITY OF THE TRANSFER TUNNEL.

Figure 7. Proposed Grout/CLSM Placement in the Transfer Tunnel.

\subsubsection{Facility Modifications}

Penetration through the exterior walls of CPP-603 will be necessary at an estimated three points to provide access for grout/CLSM hoses (see Figure 1) and at least one additional point to facilitate basin water removal to ICDF (see Figure 8). In addition, modifications to the deck plates over the North and Middle Basin will be required at each placement location to provide access through the deck plates for grout/CLSM hose.

\subsubsection{Water Removal System Design}

Inside of CPP-603A, water will be pumped from below the water surface of the overflow pit. This location was selected because it is expected to be the location least impacted by suspended solids potentially resulting from grout/CLSM placement activities until near the end of pumping activities. Figure 8 provides a schematic drawing of the proposed basin water removal system. As grout/CLSM is being placed nearer to the overflow pit, pumping frequency may have to be decreased to allow suspended solids to settle. Basin water will be pumped through piping by a centrifugal pump. The basin water will then pass through several valves prior to entering a duplex filter skid. The filter skid will be valved in such a way as to allow the filters to be operated independently or, if necessary, in parallel. A transmitter on a three valve manifold is built into the assembly to monitor the pressure drop across the filters to indicate when the filters reach full capacity. Once the filters reach full capacity, they will be replaced and 
the spent filters will be managed appropriately based on the results of analysis of representative samples of the filtered media. If the filters are determined to be LLW, they may be managed on-site. If the filters are determined to be hazardous or mixed waste, they will be managed off-site. A sample port is located downstream of the duplex filters to provide sampling access to allow the basin water to be monitored as necessary after filtration. The water being pumped to ICDF will be monitored for TSS, $\mathrm{pH}$, and radionuclides at a minimum on a per batch basis A totalizing flow meter is included in the discharge piping to monitor flow rates and volumes before the drain pipe exits CPP-603. The piping system then transitions to HDPE piping to transfer the basin water to the ICDF evaporation ponds.

2.4.4.1 Water Treatment. As grout/CLSM is placed in the CPP-603A basins, the displaced water is pumped to ICDF. The water being pumped to the ICDF evaporation ponds will be sampled at least daily during dewatering/grouting operations. A sample of the water being pumped to ICDF will be collected from the sample port downstream of the duplex filters as shown in Figure 8 and monitored for $\mathrm{pH}$ using a portable $\mathrm{pH}$ meter, even though laboratory testing conducted at INTEC have indicated that the ICDF WAC for $\mathrm{pH}$ will not be exceeded as a result of grout/CLSM addition. Total suspended solids (TSS) will also be monitored using a portable opacity meter. Calculations based on specific radioisotopes, indicates that maintaining TSS concentrations below $500 \mathrm{mg} / \mathrm{L}$ will ensure compliance with the ICDF WAC. Should monitoring indicate the quality of the water is approaching ICDF WAC limits, sampling frequency will be increased and pumping operation will cease before any WAC limits are exceeded. Based on TSS monitoring, it will be possible to route the basin water through the duplex filters, the only treatment proposed, or, if necessary, halt pumping and allow the water to settle until the turbidity clears. Under no circumstance will water be pumped to ICDF that exceeds the acceptance criteria.

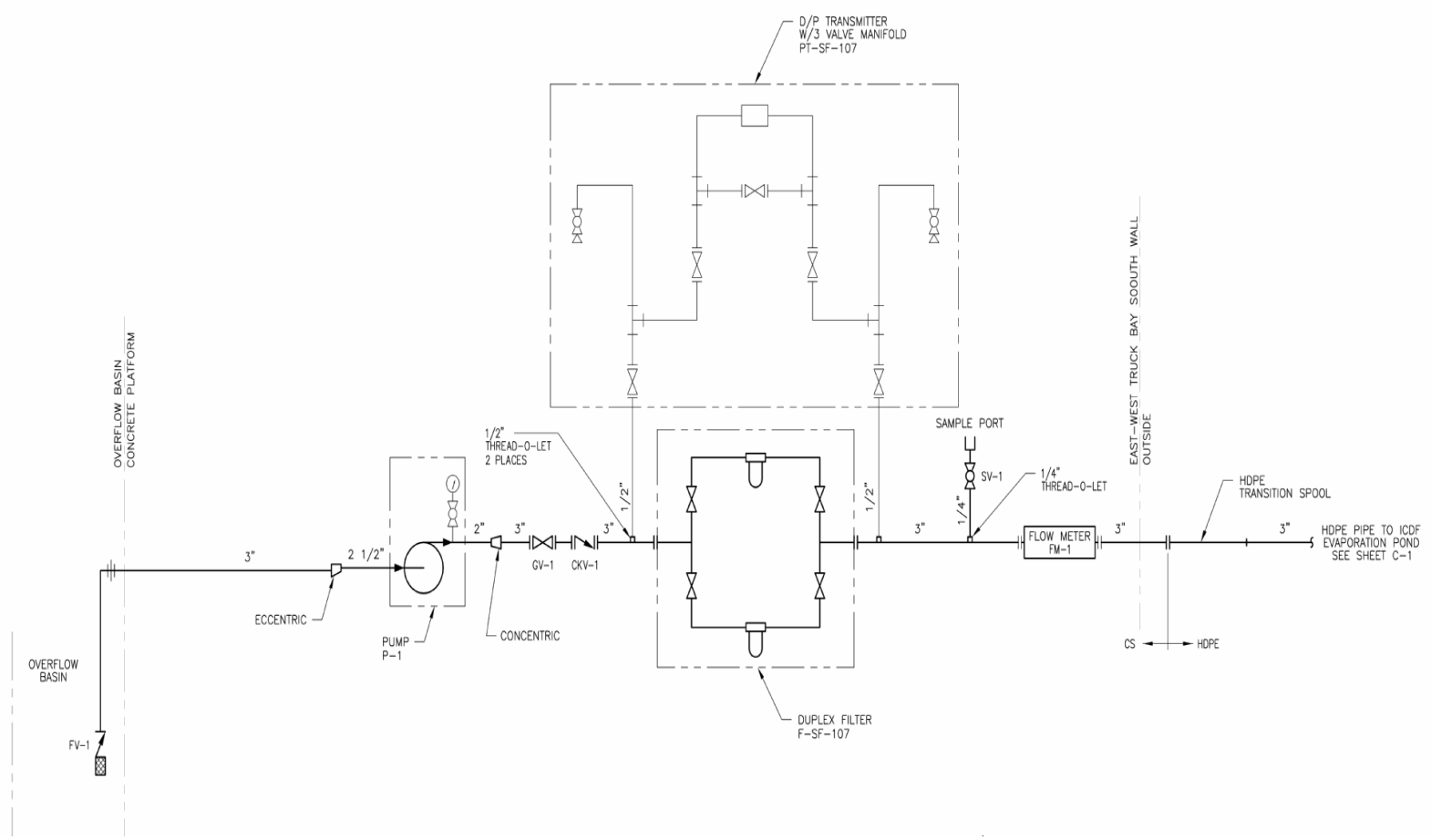

Figure 8. Water Treatment Schematic.

2.4.4.2 Water Flow Rates. The water removal system has variable speed pump to pump water from the CPP-603A basins facility to the ICDF evaporation ponds at a rate matching the rate at which grout/CLSM is being placed in the basin's underwater cavities. Grout/CLSM will be placed in the basins 
first and as the water level rises, water will be pumped from the basin at a rate that will insure that the scum line is adequately covered at all times. Dewatering/grouting activities are planned to take place on a 4-day/week, 10-hour/day schedule.

2.4.4.3 Water Piping Routing. The water removal system has been designed to remove approximately 1.4 million gallons of non-hazardous, LLW water from the CPP-603 facility and safely pump it to the ICDF evaporation ponds for disposal (see Figure 9). The basin water will be pumped from the overflow pit, located at the south end of the Transfer Canal by a centrifugal pump. A high density polyethylene (HDPE) drain pipe exists the south side of CPP-603 and runs south and west to the northeast corner of the west evaporation pond where it will enter the pond over the existing fill and will lay on| grade and extend into the evaporation pond. The drain pipe will be placed on the existing ground surface except at location where the drain pipe must cross existing roads. At road crossings (see Details 1 and 2 in Figure 9), the pipe will either run through existing culverts, where available, or be placed in new excavations approximately 1 foot deep inside of a steel containment pipe that has been bedded in sand and then cover with compacted crushed gravel backfill. The pipe will be marked in accordance with the requirements of the Radcon Manual and will be marked to make it visible to workers in the area. 


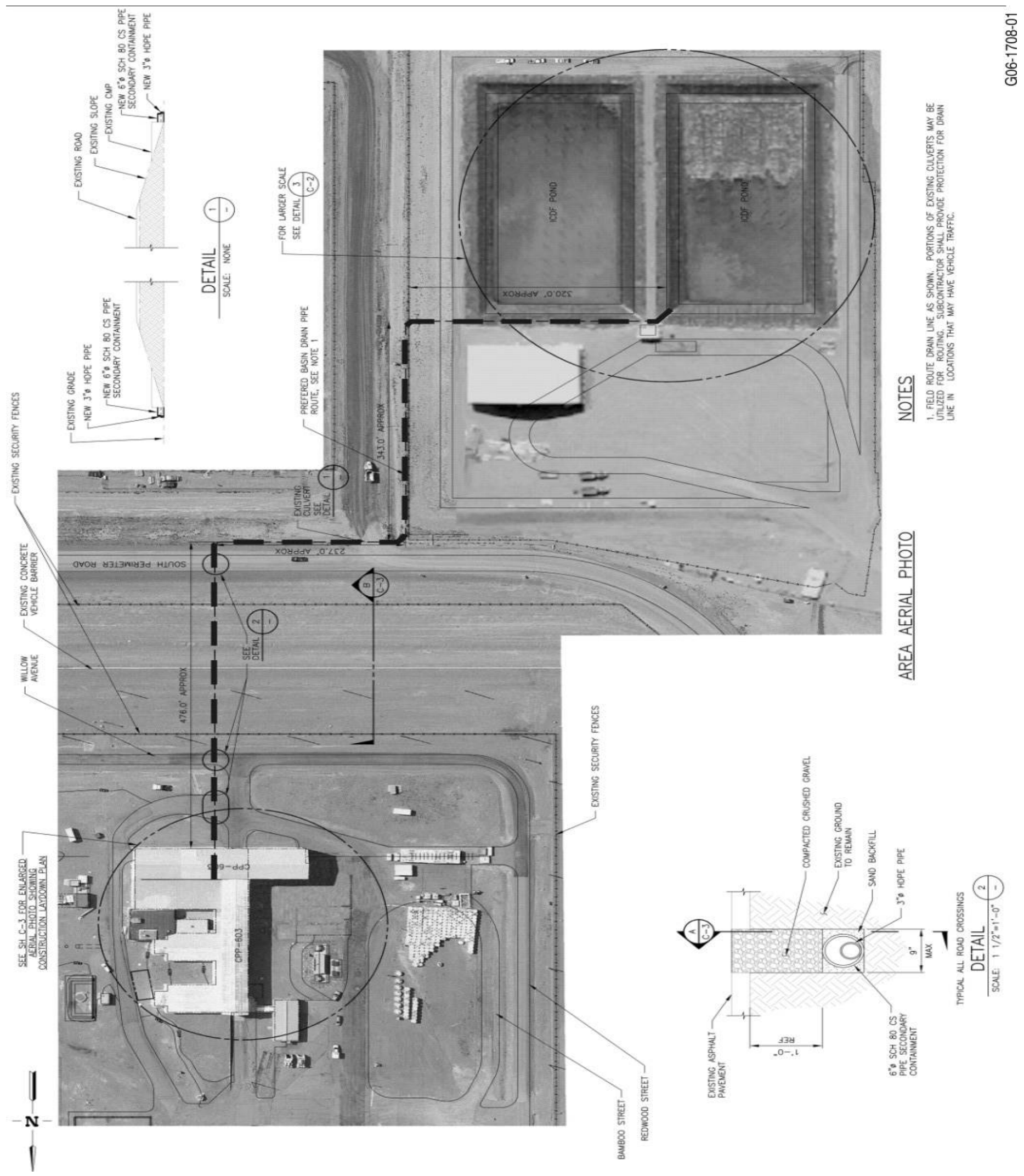

Figure 9. Aerial View of the Proposed Basin Water Transfer Pipe. 
2.4.4.4 Water Pipeline Material and Construction. As shown in Figure 8, all metallic piping inside of CPP-603 is carbon steel piping. Just outside of CPP-603, the piping transitions to HDPE pipe to transfer the basin water to the evaporation pond.

2.4.4.5 Freeze Protection. No allowances have been made to preventing freezing in the drain pipe because water will only be transferred when there is not a threat of freezing. However, if the project extends into the period of freezing weather, precautions will be taken to prevent freeze up, such as blowing out the line with low pressure air.

2.4.4.6 Secondary Containment. The water being transferred through the drain pipe is not HWMA/RCRA regulated waste requiring secondary containment. However, because the water is radiologically contaminated, the entire length of the drain pipe, with the exception of roadway crossings, is amenable to daily visual inspection to confirm integrity. Those sections of pipe that cannot be readily inspected will be secondarily contained to allow for visual leak detection.

\section{COST AND SCHEDULE}

The estimated cost of the CPP-603A basin facility's removal action is $\$ 14$ to $\$ 17$ million, which includes sludge removal, treatment, and disposal. This estimate covers the work specified in this Removal Action Work Plan.

The actual start date for the removal action is early in 2005 , but the revised schedule will depend on completion of basin sludge removal and approval of the required documentation. Revision of this document has been delayed until the basin sludge was successfully managed and a definitive plan to remove, treat, and dispose of the basin water at the ICDF evaporation ponds and fill the basins with grout/CLSM was developed. The documentation required includes this revised Removal Action Work Plan, Management Self-Assessment, sampling and analysis plans, other applicable safety documentation, work orders, and work permits. The scheduled completion date for the first action in this Removal Action Work Plan, consolidation of the cobalt-60 activated debris, was completed in January 2005. Removal and management of the SHADO 1 was completed at the end of March 2005. Following completion of the detailed design and engineering effort, DOE will initiate project mobilization in April 2006. The management self-assessment for dewatering and grouting will be completed in June 2006. Water removal to the ICDF and grout/CLSM placement will begin in approximately July 2006, and will be completed by October 2006. Removal action closeout and the final removal action report will be completed by approximately the end of December 2006. A summary of the proposed schedule is provided in Table 2 below.

Table 2. CPP-603A removal action schedule.

\begin{tabular}{ll}
\multicolumn{1}{c}{ Task } & \multicolumn{1}{c}{ Estimated Completion Date } \\
\hline $\begin{array}{l}\text { Consolidate cobalt-60 activated debris } \\
\text { Remove and relocate SHADO 1 }\end{array}$ & January 2005 - Completed \\
$\begin{array}{l}\text { Project Mobilization } \\
\text { Complete the management self-assessment for dewatering and }\end{array}$ & March 2005 - Completed \\
grout/CLSM placement & June 2006 \\
$\begin{array}{l}\text { Complete the water removal/disposal and grout/CLSM placement } \\
\text { Complete the removal action closeout and final removal action } \\
\text { report }\end{array}$ & October 2006 \\
\hline SHADO = small high-activity debris object & \\
\hline
\end{tabular}




\section{PROJECT CLOSEOUT}

At the conclusion of the removal action activities, a final removal action report will be issued. The final removal action report will include a complete documentation of the response operation and the actions taken. It will include a summary of events; an analysis of the effectiveness of the removal action activities; a list of problems impacting the response, if applicable; and any DOE recommendations. The report will contain characterization data, a description of the final facility status, and photos of the removal action project.

This report will summarize all phases of the removal action. The final removal action report will provide a formal overview of project activities, accomplishments, final status, and lessons learned.

\section{REFERENCES}

40 CFR 262.34, 2004, “Accumulation Time,” Code of Federal Regulations, Office of the Federal Register, October 2004.

40 CFR 268.7, 2005, "Testing, Tracking, and Recordkeeping Requirements for Generators, Treaters, and Disposal Facilities," Code of Federal Regulations, Office of the Federal Register, January 2005.

40 CFR 268.48, 2005, "Universal Treatment Standards," Code of Federal Regulations, Office of the Federal Register, January 2005.

42 USC $\S 6901$ et seq., 1976, "Resource Conservation and Recovery Act (Solid Waste Disposal Act)," United States Code, October 21, 1976.

42 USC $\S 9601$ et seq., 1980, "Comprehensive Environmental Response, Compensation and Liability Act of 1980 (CERCLA/Superfund)," United States Code, December 11, 1980.

DOE-ID, 1999, Final Record of Decision Idaho Nuclear Technology and Engineering Center, Operable Unit 3-13, DOE/ID-10660, Rev. 0, U.S. Department of Energy Idaho Operations Office; U.S. Environmental Protection Agency, Region 10; Idaho Department of Environmental Quality, October 1999.

DOE-ID, 2004, Engineering Evaluation/Cost Analysis for the CPP-603A Basin Non-Time Critical Removal Action, Idaho Nuclear Technology and Engineering Center, DOE/NE-ID-11140, Rev. 1, U.S. Department of Energy Idaho Operations Office, August 2004.

DOE-ID, 2005, Action Memorandum for the Non-Time Critical Removal Action at the CPP-603A Basins, Idaho Nuclear Technology and Engineering Center, DOE/NE-ID-11194, Rev. 0, U.S. Department of Energy Idaho Operations Office, January 2005.

EPA, 2002, Test Methods for Evaluating Solid Waste, Physical/Chemical Methods, SW-846, Rev. 6, U.S. Environmental Protection Agency, Office of Solid Waste, August 2002.

Idaho Code § 39-4401 et seq., 1983, "Hazardous Waste Management Act of 1983," State of Idaho, Boise, Idaho.

INEEL, 2000, HWMA/RCRA Less Than 90-day Generator Closure Report for the VES-SFE-126, INEEL/EXT-2000-00582, Rev. 0, Idaho National Engineering and Environmental Laboratory, May 2000. 